\title{
ANALYSIS OF THE RESULTS OF IMPLANTATION OF TOTAL HIP ENDOPROTHESIS IN SEVERE DYSPLASTIC COXARTHROSIS
}

\author{
Viktor Kamnar, Anastasika Poposka, Nenad Atanasov, Milena Bogojevska
}

University Traumatology, Orthopaedic, Anasthesia, Reanimation and Intensive Care And Urgent Centre, Skopje, R. Macedonia

Corresponding Author: Ac. Dr. Viktor Kamnar M. Sci. University Traumatology, Orthopaedic, Anasthesia, Reanimation and Intensive Care And Urgent Centre, Ul. Vodnjanska 17, 1000 Skopje, R. Macedonia, Tel.+389 (0)2 754437 79, E-mail: kamnar25@gmail.com

\begin{abstract}
Background: The aim of this study is to affirm the importance of operative treatment of severe dysplastic coxarthrosis through analysis of the results of implantation of total cementless endoprothesis in patients with DDH Crowe types III and IV.

Patients and methods: This retrospective study involved 28 patients (30 hips) with dysplastic coxarthrosis, in whom an implantation of cementless total hip endoprothesis was performed at the University Clinic for Orthopaedic Surgery in Skopje. In 26 of the patients the involvement was unilateral and in two patients it was bilateral. The inclusion criterion was radiographically proved severe hip dysplasia Crowe types III and IV. Twenty-one of the patients were female and 7 male, and age distribution was in an interval from 30 to 65 years. The ingrowth of the implant was evaluated using the clinical method, native radiographs and radioisotopic examination with Tc99m. The follow-up period lasted 5 years, and the results were evaluated using the Harris hip score system.

Results: 19 of the patients presented an excellent result of the operative treatment, there were 8 good results with persistent local pain 6 months postoperatively, in one case a surgical revision and reimplantation of the acetabular cup was performed, while one patient underwent a surgical revision and reimplantation of the femoral stem and in another patient there was nonunion at the place of the subtrochanteric osteotomy. Full weight-bearing without the use of crutches was achieved 3 months postoperatively, and no serious early postoperative complications were registered in our patients.

Discussion and conclusions: In the majority of cases in whom a total hip replacement with cementless endoprothesis is performed because of dysplastic coxarthrosis, a sufficient primary fixation both of the acetabular and the femoral component is achieved, unless one-third of the acetabular cup is left uncovered with bone stock. The problems of decreased muscle strength and limping are usually solved by means of physical therapy in a time period of 45 months.
\end{abstract}

Key words: Developmental Dysplasia of the Hip, Crowe Classification, Cementless Total Hip Replacement, Harris Hip Score.

\section{Introduction}

Developmental dysplasia of the hip is a congenital disease that is characterized by inadequate development of the hip with impaired ossification of the lateral acetabular epiphysis accompanied with displacement of the femoral head from its central position in the acetabulum [1]. The patients have a limp from the child- hood and intermittent aches in the groin or thigh area. The pain starts to become more severe in the third and fourth decade of life [2]. In that period the patient becomes determined that they need to undergo a surgical procedure.

The surgical treatment of dysplastic coxarthrosis by the use of cementless endoprosthetic replacement of the hip requires a smart so- 
lution in order to overcome the enormous number of anatomical and functional disorders imposed by the basic disease. Among the problems that should be bridged with this type of operative intervention we refer to the following:

- Anterior and lateral dysplasia of the acetabulum

- Deformity in the proximal femur

- Muscle imbalance

- Leg length discrepancy

There are numerous possible solutions regarding the problem of dysplastic coxarthrosis in the orthopaedic surgery. Among the many rational solutions there are several that impose as appropriate:

- Solution for the acetabular dysplasia or the neoacetabular coxarthrosis with the use of cementless endoprosthesis without the use of supraacetabular reconstruction such as the Harris procedure or metal augmentation.

- Use of a small and perforated acetabular cup, placed in the true acetabulum.

- A dysplastic polyethylene liner that would cover $2 / 3$ of the dysplastic acetabulum.

- At the same time, achievement of a good press fit fixation.

By using the mentioned solutions we achieved:

- Correction of the anteversion of the acetabulum and the antetorsion in the procimal femur.

- Correction of the leg length discrepancy.

- Correction of the imbalance of the soft tissue around the hip.
In cases with severe congenital dislocation, known as neoacetabular coxarthrosis (Crowe types III and IV) the orthopaedic surgeon faces a great challenge. Placement of the acetabular component in the true acetabulum can lead to significant lengthening of the leg, which can result in nerve injury. This problem is solved with subtrochanteric shortening osteotomy of the femur, which requires a thorough knowledge of the anatomy, as well as total mastery of the operative technique [3]. Enormous attention should be paid to a correct reconstruction of the soft tissues around the hip. If the operation is performed properly, it leads to lasting and functional hip replacement.

\section{Material and methods}

This retrospective study was conducted on 28 patients with dysplastic coxarthrosis, of whom 26 had unilateral involvement, and two patients had bilateral developmental dysplasia of the hip. All of them were treated with cementless total replacement of the hip at the Universisty Orthopaedic Surgery Clinic in Skopje. 21 of the patients were female and 7 were male, age distribution from 30 to 65 years.

\section{Inclusion criteria}

We included patients whose radiographic findings displayed severe dislocation of the hip according to Crowe types III and IV (Table 1). Eighteen of the hips were classified as Crowe type III, while the remaining 12 were classified as Crowe type IV.

Table 1

Classification of adult developmental dysplasia of the hip according to Crowe

\begin{tabular}{|l|l|l|l|}
\hline \multicolumn{1}{|c|}{ Section 1 - The patient answers the following eight questions with one of the answers given: } \\
\hline None, or ignores it & \multicolumn{1}{|c|}{ II. Support } & III. Distance walked & IV. Limp \\
\hline $\begin{array}{l}\text { Slight, occasional, no compromise in } \\
\text { activity }\end{array}$ & $\begin{array}{l}\text { None } \\
\text { Cane/Walking stick for } \\
\text { long walks }\end{array}$ & $\begin{array}{l}\text { Six blocks (30 } \\
\text { minutes) }\end{array}$ & Slight \\
\hline $\begin{array}{l}\text { Mild pain, no effect on average activities, } \\
\text { rarely moderate pain with unusual activity, } \\
\text { may take aspirin }\end{array}$ & $\begin{array}{l}\text { Cane/Walking stick most } \\
\text { of the time }\end{array}$ & $\begin{array}{l}\text { Two or three blocks } \\
\text { (10-15 minutes) }\end{array}$ & Moderate \\
\hline $\begin{array}{l}\text { Moderate pain, tolerable but makes conces- } \\
\text { sions to pain. Some limitations of ordinary } \\
\text { activity or work. May require occasional } \\
\text { pain medication stronger than aspirin }\end{array}$ & One crutch & Indoors only & $\begin{array}{l}\text { Severe or } \\
\text { unable to } \\
\text { walk }\end{array}$ \\
\hline Marked pain, serious limitation of activities & Two Canes/Walking sticks & Bed and chair only & \\
\hline $\begin{array}{l}\text { Totally disabled, crippled, pain in bed, } \\
\text { bedridden }\end{array}$ & $\begin{array}{l}\text { Two crutches or not able } \\
\text { to walk }\end{array}$ & & \\
\hline
\end{tabular}




\begin{tabular}{|l|l|l|l|}
\hline $\begin{array}{l}\text { V. Activities - shoes, } \\
\text { socks }\end{array}$ & VI. Stairs & $\begin{array}{l}\text { VII. Public } \\
\text { transportation }\end{array}$ & \multicolumn{1}{|c|}{ VIII. Sitting } \\
\hline With ease & $\begin{array}{l}\text { Normally without using a } \\
\text { railing }\end{array}$ & $\begin{array}{l}\text { Able to use } \\
\text { transportation (bus) }\end{array}$ & $\begin{array}{l}\text { Comfortably, ordinary } \\
\text { chair for one hour }\end{array}$ \\
\hline With difficulty & Normally using a railing & $\begin{array}{l}\text { Unable to use public } \\
\text { transportation (bus) }\end{array}$ & $\begin{array}{l}\text { On a high chair for 30 } \\
\text { minutes }\end{array}$ \\
\hline Unable to fit or tie & In any manner & $\begin{array}{l}\text { Unable to sit comfort- } \\
\text { tably on any chair }\end{array}$ \\
\hline & Unable to climb stairs & & \\
\hline
\end{tabular}

\section{Materials}

The types of endoprosthetic replacement material that we used in the operative treatment of the dysplastic coxarthrosis were those used in standard procedures - Zimmer and Jonhson \& Jonhson.

\section{Surgical technique}

All the patients had undergone preoperative clinical examination, measurement of the leg length was performed, radiographs and determination of the Harris Hip Score. The preoperative radiographs were used to template the endoprosthetic components, as well as to determine the position, dimension, depth and angle of anteversion of the false and true acetabulum, the bone stock that is at disposal in the true acetabulum, and the shape of the femur, as well as the need to shorten it. Only standard endoprosthetic material was available. All the operations were performed by the same team of surgeons.

All the patients were operated under spinal anaesthesia. We used an antero-lateral approach. With careful preparation of the periarticular structures we approached the joint itself. After the femoral neck appeared it was resected with a power saw and removed. Then the true acetabulum was identified. Acetabular preparation implies removal of the pulvinar and reaming of the reestablished true acetabulum in physiological anteversion of 10 degrees and abduction of 45 degrees. Placement of the acetabular component was completed with screw fixation. After careful manual dragging of the proximal part of the femur distally, paying attention at the same time not to injure the sciatic nerve, we assed the need of additional femoral resection. Because of elongation greater than 3 to $4 \mathrm{~cm}$ in the leg length, in 7 of the patients we needed to perform shortening of the femur. The next step was reaming of the femoral part as well as definite implantation of the femoral component, which was also used as an intramedullary osteosynthetic material if femoral resection was performed. Following these steps, we proceeded towards reduction of the hip and checking the possibility of dislocation of the components. After placement of the drainage and soft tissue reconstruction, the patient left the operating room when the closure of the wound was complete.

\section{Postoperative treatment and evaluation of the results}

Our team proceeded towards walking exercises the day following the operation. Antibiotic prophylaxis was conveyed in all the patients. Patients started gradually with weight bearing when walking, leading to complete weight-bearing and walking without crutches 6 months after the operative interventions in all the patients.

The incorporation of the total hip endoprosthesis was evaluated by the use of the clinical method, roentgenogram analysis and body scan with Tc99m. The patents' follow-up lasted 5 years.

The results were evaluated with the Harris Hip Score (Table 2) [4]. A successful result meant a postoperative increase in the Harris Hip Score of more than 20 points accompanied by a radiographically stable implant (Figure 1) with no additional femoral reconstruction.

Table 2

Harris Hip Score Grading. HHS < 70 Poor result, 70-79 Fair, 80-89 Good, 90-100 Excellent

\begin{tabular}{|l|}
\hline $\begin{array}{l}\text { Section } 2 \text { - To score this section all four must } \\
\text { be 'yes', then get } 4 \text { points }\end{array}$ \\
\hline Less than 30 degrees of fixed flexion \\
Less than 10 degrees of fixed int rotation in extension \\
Less than 10 degrees of fixed adduction \\
Limb length discrepancy less than $3.2 \mathrm{~cm}(1.5$ inches $)$ \\
\hline Section 3 - Motion \\
\hline Total degrees of flexion \\
\hline Total degrees of abduction \\
\hline Total degrees of external rotation \\
\hline Total degrees of adduction \\
\hline
\end{tabular}



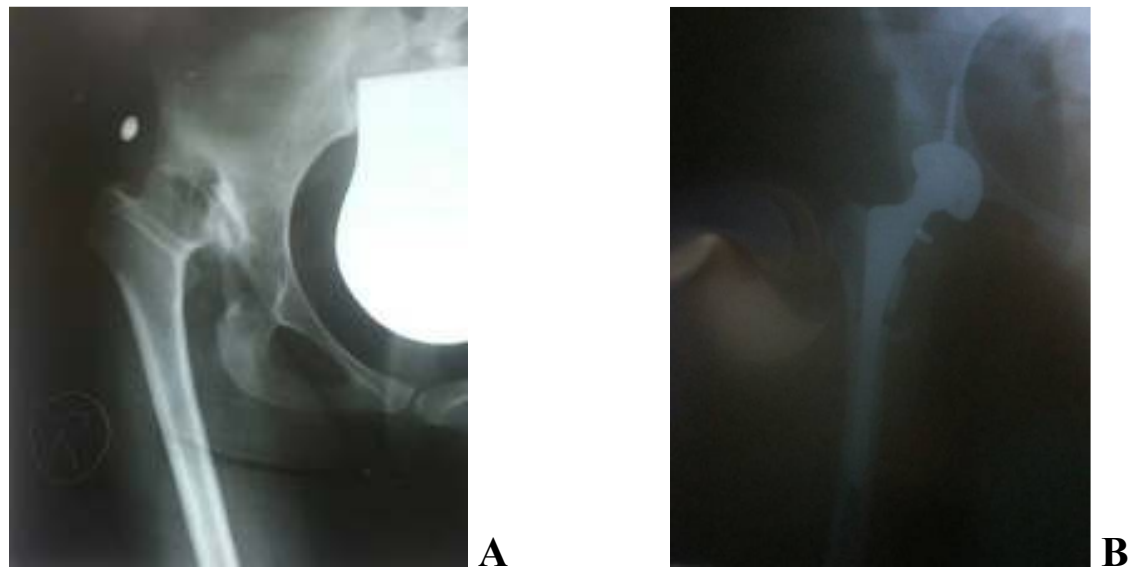

Figure 1 -Roentgenograms of hip of 55-year-old woman that represent: A. Preoperative anteroposterior Roentgenogram with dislocation of the hip Crowe type IV. B. Postoperative, placement of the acetabular cup in the true acetabulum as well as subtrochanteric shortening of the femur

\section{Results}

In the process of clinical evaluation, the analysis of the radiographs and the Tc99m scans two orthopaedic surgeons, a specialist in radiology and a specialist in nuclear medicine were involved. Anamnestically and clinically with the use of the Harris Hip Score (HHS) we reached the following results: preoperative mean value of the HHS was 41 (9-57), immediately after the operation 72 , after one year's follow-up 8; reaching 85 points (70-97) in the fifth year after the operation (Diagram 1).

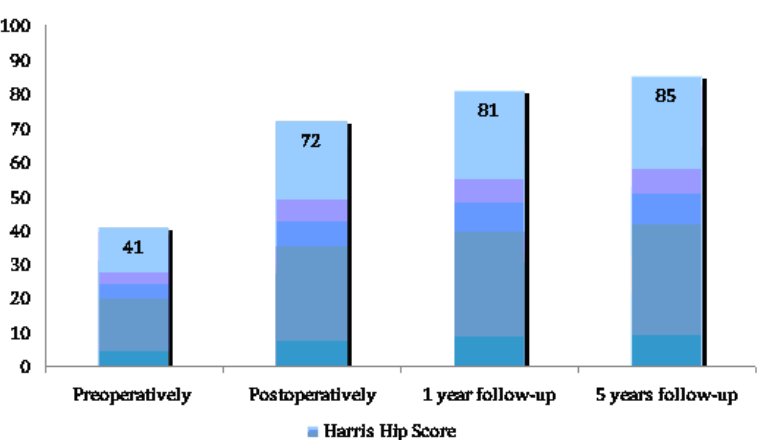

Diagram 1 - Harris Hip Scores in preoperative and different postoperative phases of follow up

In the preoperative clinical examination all the patients except one had a positive Trendelenburg sign; and in the postoperative examination the Trendelenburg sign was absent in all the patients. Leg length discrepancy was improved by a mean value of $9 \mathrm{~mm}$ postoperatively, bearing in mind the preoperative discrepancy of a mean 2.2 centimetres value. In all the patients postoperative roentgenograms were performed in different phases of the follow-up. Loosening of the stem was noticed in one patient, and a radiolucent line around the aceta- bular component appeared in another patient. In one patient there was nonunion at the place of the subtrochanteric osteotomy.

Two patients had to undergo a bone scan with Tc99m in order to enlighten the case (pain persistence without clinical and radiological changes). 19 of the operated hips had excellent results, 8 had a good result, but with persistent pain 6 months after the intervention, one case was revised and reimplantation of the acetabular component was done, there was also nonunion at the site of the subtrochanteric osteotomy 8 months after the operative intervention (Diagram 2).
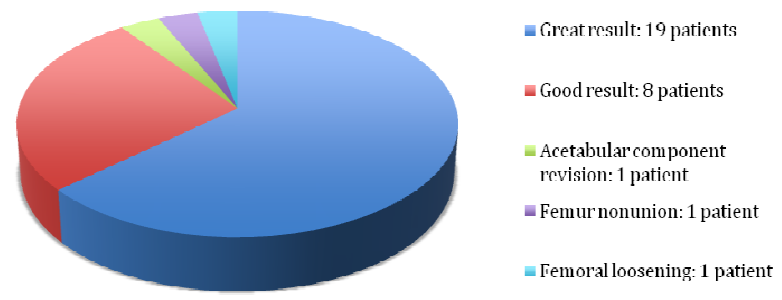

Diagram 2 -Diagram showing the results we achieved

\section{Discussion}

The question regarding high hip dislocations was first asked by Crowe, suggesting at the same time the classification for adult developmental dysplasia of the hip assessment [2]. The problems that are mentioned in his paper from 1979 as to location, fixation and size of the acetabular component are even today a matter of discussion, pointing out at the same time that the biggest bone stock is placed in the true acetabulum. That principle is clearly determined and a tendency exists to place the acetabular component in the true acetabulum (the 
percent of loosening of the acetabular component is $13 \%$ compared to its placement proximal to the true acetabulum, where the loosening frequency is $42 \%$ ). In most cases by implantation of a cementless total hip endoprosthesis to dysplastic hips good primary fixation of the acetabular and the femoral component of the replacement is achieved, always paying attention not to leave more than $1 / 3$ of the acetabular cup uncovered with bone. Whereas putting the femur in the true acetabulum leads not only to lengthening of the extremity by several centimeters, which leads to leg length discrepancy, but also to injury of the surrounding nerve structures in dislocations of Crowe type IV. Therefore, searching for an appropriate solution surgeons came across the subtrochanteric shortening of the femur, which was primarily used as a treatment for congenital hip dislocation in older children [5], but from the 1980 s has found its way in total hip replacement of the dysplastic hip [6]. Another problem that rings a bell in these patients are the contractures of the soft tissues around the joint, that seeks deliberate release of these structures, beginning from the joint capsule, to the adductors, abductors and other muscles around the hip, giving special attention to the gluteus medius muscle, that represents the main force in the abductors in the hip, having an important role in stability and movement [7].

\section{Conclusion}

The essence of the technique we use is constructing normal biomechanics by complex remodelling of the disturbed biology. The increase of the Harris Hip Score from the preoperative 41 points to the postoperative 85 (postoperative increase in Harris Hip Score of 44 points) in these patients proves the efficiency of the method that we used in patients with Crowe types III and IV dysplasia.

Type I hips have less than $50 \%$ subluxation Type II hips have between $50 \%$ and $75 \%$ subluxation Type III hips have between $75 \%$ and $100 \%$ subluxation Type IV hips have more than $100 \%$ subluxation

\section{REFERENCES}

1. Pediatric orthopedics in practice: Hefti, Fritz; Brunner, Reinald; Hasler, Carol C; Jundt, Gernot. Heidelberg; New York : Springer Medizin. 2007. [Book] NLMCatalog [catalog record]NLM ID: 101307534.
2. JF Crowe, VJ Mani and CS Ranawat J. Total hip replacement in congenital dislocation and dysplasia of the hip Bone Joint Surg Am. 1979; 61: 15-23.

3. Oe K, Iida H, Nakamura $T$, Okamoto $N$, Wada $T$. Subtrochanteric shortening osteotomy combined with cemented total hip arthroplasty for Crowe group IV hips. Arch Orthop Trauma Surg. 2013; Dec; 133(12): 1763-70.

4. Harris WH. Traumatic arthritis of the hip after dislocation and acetabular fractures: treatment by mold arthroplasty. An end-result study using a new method of result evaluation. J Bone Joint Surg Am. 1969; Jun; 51(4): 737-55.

5. Klisic P, Jankovic L. Combined procedure of open reduction and shortening of the femur in treatment of congenital dislocation of the hips in older children. Clin Orthop Rel Res. 1976; 119: 60-69.

6. Sponseller PD, McBeath AA. Subtrochanteric osteotomy with intramedullary fixation for arthroplasty of the dysplastic hip. A case report. J Arthropl. 1988; 3: 351-354.

7. Pengfei Lei, MD; Yihe Hu, MD; Pengde Cai, MD; Jie Xie, MD; XuCheng Yang, MD; Long Wang, MD. Greater Trochanter Osteotomy With Cementless THA for Crowe Type IV DDH. Haelio Orthopedics. May 2013. Volume 36. Issue 5: e601-e605.

8. Krych AJ, Howard JL, Trousdale RT, Cabanela ME, Berry DJ. Total hip arthroplasty with shortening subtrochanteric osteotomy in Crowe type-IV developmental dysplasia. J Bone Joint Surg Am. 2009 Sep; 91(9): 2213-21.

9. Stans AA, Pagnano MW, Shaughnessy WJ, Hanssen AD. Results of total hip arthroplasty for Crowe Type III developmental hip dysplasia. Clin Orthop Relat Res. 1998 Mar; (348): 149-57.

10. Nawabi DH, Meftah M, Nam D, Ranawat AS, Ranawat CS. Durable Fixation Achieved With Medialized, High Hip Center Cementless THAs for Crowe II and III Dysplasia. Clin Orthop Relat Res. 2014 Feb; 472(2): 630-6.

11. Togrul E, Ozkan C, Kalaci A, Gülşen M. A new technique of subtrochanteric shortening in total hip replacement for Crowe type 3 to 4 dysplasia of the hip. J Arthroplasty. 2010 Apr; 25(3): 465-70. doi: 10.1016/j.arth.2009.02.023. Epub 2009 Jul 4.

12. Sanchez-Sotelo J, Berry DJ, Trousdale RT, Cabanela ME. Surgical development of developmental dysplasia of the hip in the adults. II: arthroplasty options. J Am Acad Orthop Surg. 2002; 10: 334-40.

13. Numair J, Joshi AB, Murphy JC, Porter ML, Hardinge K. Total hip arthroplasy for congenital dysplasia or dislocation of the hip: survivorship analysis and long term results. J Bone Joint Surg [Am]1996; 79-A: 1352-60.

14. MacKenzie JR, Kelley SS, Johnston RC. Total hip replacement for coxarthrosis secondary to congenital dysplasia and dislocation of the hip: long-term results. J Bone Joint Surg [Am]. 1996; 78-A: 55-61.

15. Klapach AS, Callaghan JJ, Miller KA, et al. Total hip arthroplasty with cement and without acetabular bone graft for severe graft dysplasia: a concise follow-up, at a minimum of twenty years, of a previous report. J Bone Joint Surg [Am]. 2005; 87-A: 280-5. 
16. Chougle A, Hemmady MV, Hodgkinson JP. Longterm survival of the acetabular component after total hip arthroplasty with cement in patients with developmental dysplasia of the hip. J Bone Joint Surg [Am]. 2006; 88-A: 71.

17. Iida H, Matsusue Y, Kawanave K, et al. Cemented total hip arthroplasty and acetabular bone graft for developmental dyspasia: long-term results and survivorship analysis. J Bone Joint Surg [Br]. 2000; 82B: $176-84$.

18. Hartofilakidis G, Karachalios T. Total hip arthroplasty for congenital hip disease. J Bone Joint Surg [Am]. 2004; 86-A: 242-50.

19. Jasty M, Anderson MJ, Harris WH. Total hip replacement for developmental dysplasia of the hip. Clin Orthop. 1995; 311: 40-5.

20. Charnley J, Feagin JA. Low-friction arthroplasty in congenital subluxation of the hip. Clin Orthop. 1973; 91: 98-113.

21. Sochart DH, Potret ML. The long-term results of Charnley low-friction arthroplasty for congenital dysplasia or dislocation of the hip: long-term results. J Bone Joint Surg [Am]. 1997; 79-A: 55-61.

22. Dawson J, Fitzpatrick R, Carr A, et al. Questionnaire on the perceptions of patients about total knee replacement. J Bone Joint Surg [Br]. 1996; 78: 185.

23. Fitzgerald JD, Orav EJ, Lee TH, et al. Patient quality of life during the 12 months following joint replacement surgery. Arthritis Rheum. 2004; 51: 100.

24. Freeman MA. Acetabular cup migration: prediction of aseptic loosening. J Bone Joint Surg [Br]. 1997; 79-B: 342-3.

25. Li PL, Ganz R. Morphologic features of congenital acetabular dysplasia: one in six is retroverted. Clin Orthop. 2003; 416-53.

26. Eskelinen A, Helenius I, Remes V, et al. Cementless total hip arthroplasty in patients with high congenital hip dislocation. J Bone Joint Surg [Am]. 2006; 88-A: 80-91.

Резиме

\section{АНАЛИЗА НА РЕЗУЛТАТИТЕ ОД ИМПЛАНТАЦИЈАТА НА БЕСЦЕМЕНТНА ТОТАЛНА ЕНДОПРОТЕЗА НА КОЛКОТ КАЈ ТЕШКА ДИСПЛАСТИЧНА КОКСАРТРОЗА}

\section{Виктор Камнар, Анастасика Попоска, Ненад Атанасов, Милена Богоевска}

Универзитетска клиника за трауматологија, ортопедски болести, анестезија, реанимација и интензивно лекување и Ургентен центар, Скопје, Р. Македонија

Вовед: Целта на оваа студија е низ анализа на добиените резултати да се реафирмира значењето на оперативното лекување на диспластичните коксартрози со имплантација на тотални бесцементни ендопротези.

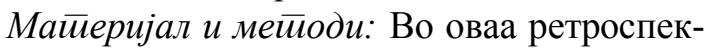
тивна студија се опфатени 28 пациенти (30 колка) со диспластична коксартроза, лекувани со имплантација на тотална бесцементна ендопротеза на колкот на Универзитетската клиника за ортопедски болести во Скопје. Кај 26 пациенти дисплазијата беше унилатерална, а кај двајца пациенти билатерална. Инклузиони критериуми беа радиографски дијагностицирана тешка дисплазија според Crowe тип III и IV. 21 пациент беа од женски, а 7 од машки пол, возрасната дистрибуција беше од 30 до 65 години. Инкорпорацијата на тоталната ендопротеза беше евалуирана со помош на клиничкиот метод, рендгенографскиот метод и сцинтиграфија со Тс $99 \mathrm{~m}$. Резултатите се следеа во период од пет години. Резултатите се евалуираа користејќи Harris Hip Score.

Резулйайи: 19 од оперираните колкови беа со одличен резултат, 8 со добар резултат и со присутна перзистентна болка до 6 месеци по оперативната интервенција, кај еден случај беше направена оперативна ревизија и реимплантација на ацетабуларната компонента, додека кај еден пациент имаше nonunion на местото на суптрохантерната остеотомија. Потполно оптоварување без помош на патерици беше постигнато три месеци по оперативниот зафат без посериозни рани постоперативни компликации.

Дискусија и заклучощи: Во најголем број случаи при имплантација на тотална бесцементна ендопротеза на колкот кај диспластични коксартрози се постигнува добра примарна фиксација на ацетабуларната и феморалната компонента на протезата, секогаш водејќи сметка да не се остави повеќе од $1 / 3$ од ацетабуларната капа непрепокриена со коска. Средната постоперативна вредност на Harris Hip Score изнесува 85. Мускулната сила и решавање на проблемот со накривувањето се надминува со помош на физикална терапија во вкупен временски период од четири и пол месеци.

Клучни зборови: развојна дисплазија на колк, бесцементна ендопротеза на колк, Crowe-класификација, Harris Hip Score. 